\title{
8. Under the Shadow: Problems in Museum Development in Asia
}

\author{
Oscar Ho
}

\section{Introduction}

In May 2012 the office of Museum Plus $(\mathrm{M}+)$, the art space to be opened in 2017 at Hong Kong's West Kowloon Cultural District (WKCD), held their inaugural exhibition of contemporary art entitled Mobile M+: Yau Ma Tei. The multi-sited exhibition was presented across various sites in the working-class neighbourhood of Yau Ma Tei at West Kowloon. Local artists were commissioned to create installations and video art on the streets with the intention of bringing art closer to the people. Lee Chun Fung, artist and director of the nearby artists' space Wufarten ${ }^{1}$ went to the Mobile $M+$ opening ceremony in a small local park. Wearing the typical neighbourhood attire of shabby singlet, shorts and slippers, he was, however, refused entry by event security for being improperly dressed for the event.

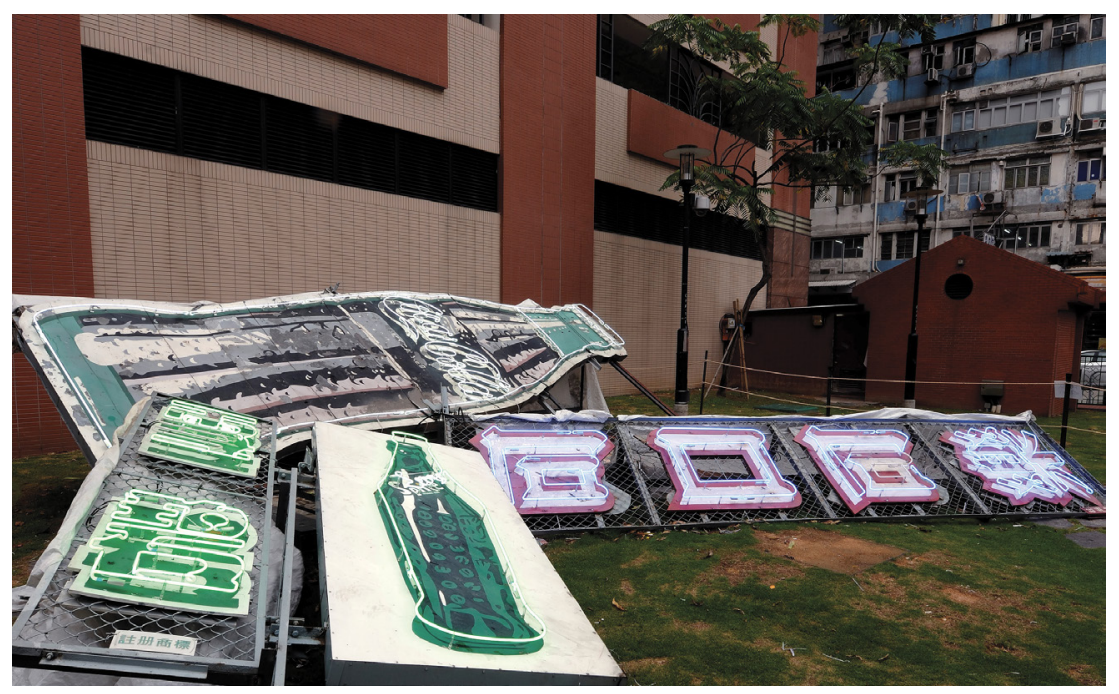

Leung Mee-ping, I Miss Fanta at Mobile M+: Yau Ma Tei 2012.

Courtesy of $\mathrm{M}+$, West Kowloon Cultural District

1 Recently closed, Wufarten was a community-focused nonprofit art organisation and space, funded by the Hong Kong Art Development Council. See http://woofer10.blogspot.hk/. 


\section{Suddenly Cultured}

Lured by the economic possibilities of the new 'cultural industries', and the desire to build national/regional pride through cultural expression, the last decade has seen Asia engage in unprecedented investment in arts and culture. New cultural venues and museums are popping up throughout Asia faster than the spread of the Starbucks global coffee chain. The rapid establishment of ambitious cultural projects has resulted in the region becoming 'suddenly cultured', and this has made clear some of the problems that have long existed within Asia's cultural infrastructure. With reference to the different objectives and outcomes of independent curatorial practices in Asia, this essay compares the original and ambitious mission for the government-supported $\mathrm{M}+$ project at WKCD against the reality of the project's implementation. The essay explores the difficulties and hindrances in museum development in Asia which, I will argue, suffers internally from infrastructural weakness and externally from Western-dominated thinking.

Asia's fast-growing cultural projects are often ambitious attempts to turn a city into a 'cultural hub' and build regional or national pride through grand displays of rich local or regional cultures. During the implementation of these projects, however, there is heavy reliance on Western 'experts', who play dominant roles in shaping the content and format of the projects.

Making reference to independent curatorial projects presented at the inaugural forum of the Asian Curatorial Network (ACN), which was held in 2011 in Hong Kong, ${ }^{2}$ and examining the process of planning and building $\mathrm{M}+$, the essay argues that underdeveloped infrastructure, conservative administrative cultures, prolongation of the colonial mindset, and Western cultural domination arising from the continuing imbalance of power and influence of curatorial practices that are led by Western thinking, continue to influence cultural development in Asia and hinder the region's ability to build a unique, locally driven language of cultural practice. It argues the necessity for curatorial practices underscored by respectful sensitivity toward the local that support efforts to seek alternative modes of operation, and that evince open-minded approaches which are attentive to local, Hong Kong cultural contexts and needs.

\footnotetext{
2 The inaugural ACN forum, Curatorial Critique: An Asian Context, was funded by the Asian Cultural Council and held at the Hong Kong Academy for Performing Arts on 24 May 2011 (organised by the Chinese University of Hong Kong's Department of Cultural and Religious Studies in association with the University of Hong Kong's Centre for Culture and Development). The event showcased curatorial practices from the perspective of independent art spaces and curators. Principal speakers at the forum included Mizuki Endo (Japan), Ringo Bunoan (Philippines), Erin Gleeson (Cambodia), Yao Jui-Chung (Taiwan), Agung Hujatnikajennong (Indonesia) and Siu King Chung (Hong Kong), with Oscar Ho as moderator and David Elliott as commentator.
} 


\section{History: Real Estate Project in Disguise}

In 2004 the Hong Kong Government announced its grand plan to build the WKCD on 40 acres of reclaimed land in the western part of Kowloon. The development plan proposed three theatres, four museums (ink, contemporary art, design and moving image), and business, hotel and residential developments. The entire district, including the cultural institutions, would be designed, built and administered by a single real estate developer - the UK architectural firm Foster + Partners, headed by the internationally famous British architect Norman Foster.

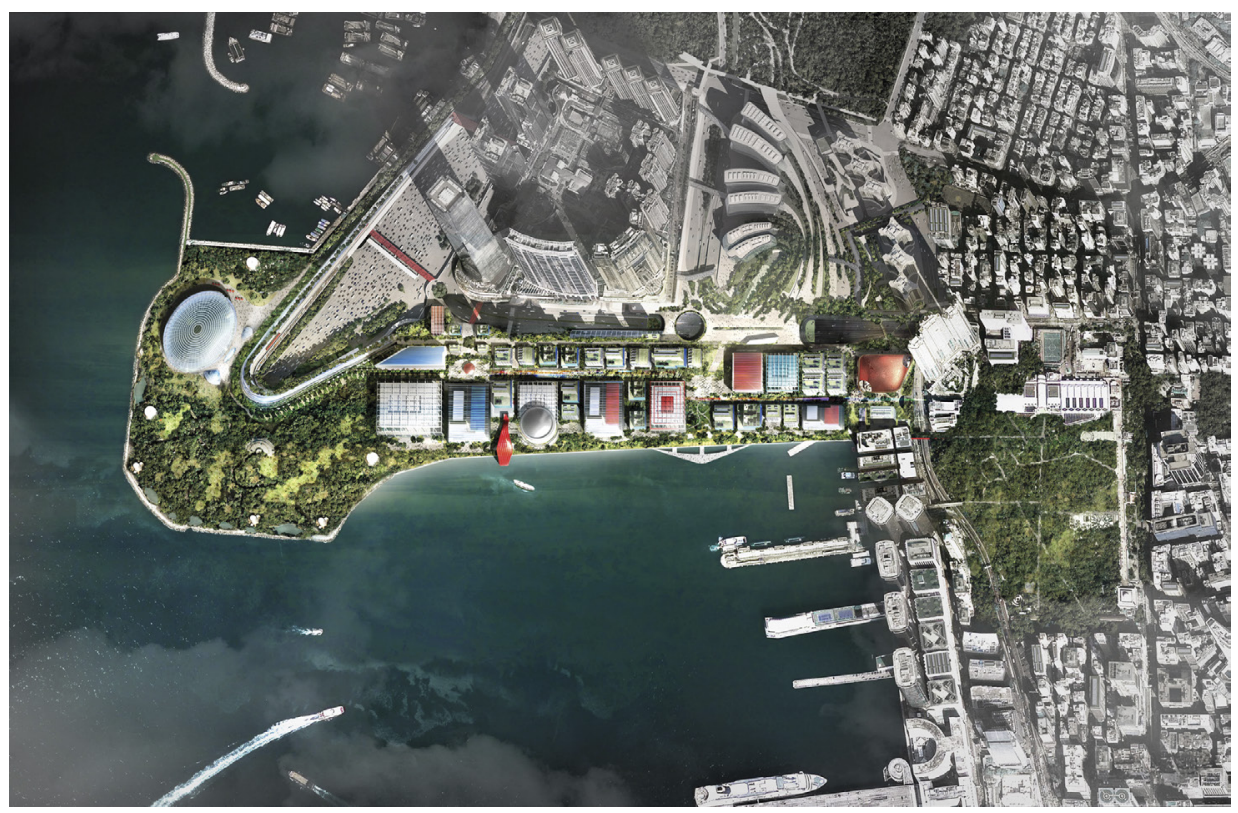

\section{Proposed plan of the future West Kowloon Cultural District.}

Courtesy of West Kowloon Cultural District Authority

Like many cultural projects in Asia (China in particular), cultural districts are frequently real estate developments in disguise. In a paper submitted to the Legislative Council in 2006, the Hong Kong Alternatives, an advocacy group of architects, solicitors and other professionals, asserted that 'WKCD is not for Sale! Not for commercial property development!' ${ }^{3}$ As evidence of the real purpose

3 Hong Kong Alternatives, 'An Appeal to Develop WKCD as West Kowloon Cultural Green Park as a Legacy for Hong Kong' (2006), accessed 11 April 2014, http://www.hkalternatives.com/Eng/downloads/Position_ Papers/LEGCO-2006-0918-HKA-Position-Paper-Eng.pdf. 
of the development, social activist Chu Hoi Dick collected news clippings recording the enthusiastic responses of developers to the commercial potential of the project, which was clearly their sole interest. ${ }^{4}$

A survey conducted by the University of Hong Kong in 2005 revealed that over 60 per cent of interviewees felt that allocating 60 per cent of the district for residential and commercial use was too high, and 85 per cent opposed the proposal to only allow real estate developers to bid on the land. ${ }^{5}$

The proposal was also criticised by the arts and professional communities as hypocritical, lacking interest in professional considerations, and deficient in its vision, as well as for not being open to smaller real estate developers that lacked the finances to participate in such a grand project. In the face of this public outcry, the government withdrew the original proposal and invited professionals and representatives from the community to rework the plan.

A revised plan was presented in 2009 and officially approved in 2011. With a budget of HK\$21.6 billion (US $\$ 2.8$ billion), the new plan proposed the building of 14 theatres/music halls, one exhibition centre and the $\mathrm{M}+$ art space.

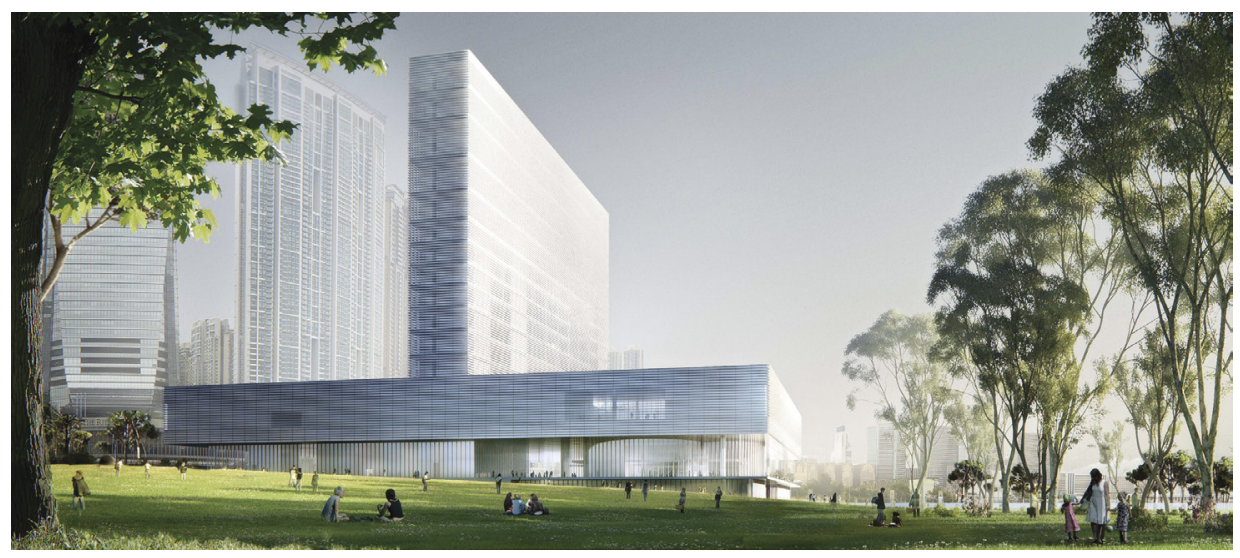

\section{View of $M+$ from the Park at WKCD-next to a tree-lined avenue along the waterfront [Proposal].}

Courtesy of Herzog \& de Meuron and West Kowloon Cultural District Authority

\footnotetext{
4 Chu Hoi Dick, ‘西九文化區報摘之果然係地產項目' ('West Kowloon is in Fact a Real Estate Development'), Independent Media, 15 September 2007, http://www.inmediahk.net/node/257529.

5 Robert Ting-Yiu Chung, Karie Ka-Lai Pang \& Kitty Suet-Lai Chan, 'Planning for West Kowloon and the Harbour Front Opinion Survey: Summary of Findings', The University of Hong Kong Public Opinion Program (University of Hong Kong, 21 January 2006), 14-16, accessed 1 April 2014, http://www.harbourdistrict.com. hk/enews/20060123/Summary_of_Survey_Findings.pdf.
} 
Occupying 60,000 square metres with a budget of HK\$4.7 billion(US $\$ 600$ million), $\mathrm{M}+$ is an unprecedented undertaking for Hong Kong. More significant is that, in its original plan, $\mathrm{M}+$ sought to introduce a new mode of 'museum' curation and presentation informed by a wider field of interdisciplinary visual culture practice, reflective of not just local Hong Kong cultural experience, but also new thinking about museums.

Before discussing the curatorial directions of $\mathrm{M}+$, I would like to shift the discussion to the 2011 inaugural forum of the Asian Curatorial Network (ACN), referred to earlier. The forum focused on curatorial approaches employed by independent Asia-based curators. The presentations revealed interesting curatorial adaptations of and reactions to the particular cultural ecologies of Asia that, in many ways, resonated with the initial guiding principles in the planning of $\mathrm{M}+$.

Supply and control of resources shapes and dictates curatorial approaches and modes of operation. In Asia, where there is substantial government involvement in the arts, but no strong philanthropic tradition supporting creative endeavours, the government holds substantial control over resource allocation for cultural development. Curators working outside the official establishment survive with extremely limited resources. This situation often gives rise to small-scale alternative spaces that seek autonomy from government-defined cultural programs. Such spaces have become important forces in shaping the region's cultural development.

At the ACN forum, the Filipino artist/curator Ringo Bunoan used Shop 6, an artist-run space created in 1974 by Filipino conceptual artist Roberto Chabet, as an example of an attempt to address the problem of 'lack of alternative spaces and support for alternative art'. Bunoan demonstrated the influence of alternative spaces and the continuous dynamic they generate in the Philippines art scene. Similarly in Indonesia, the absence of state-run spaces for the exhibition of alternative art has led to the establishment of an array of independent artist spaces, such as the Cemeti Art House in Yogyakarta.

These independent, humble spaces are usually located in urban, frequently working-class, neighbourhoods where they often interact with and respond to their local community. ${ }^{6}$ A typical example of this kind of engagement in Hong Kong is the recently closed artist space Wufarten at Yau Ma Tei, mentioned at the outset of this essay, which focused on the presentation of art and crafts that were made by people living within its surrounding working-class neighbourhood. The Wufarten art space aimed to 'introduce a lively conception of contemporary art engaging the community'. As their blog explains in describing their mission,

6 There are always exceptions, such as Hong Kong's Para Site, which although an independent art space, focuses on contemporary Hong Kong and international artists rather than its immediate local community. 
'instead of attempting an out-of-place, arty white-cube gallery, Woofer Ten [Wufarten] mold[ed] itself more like a community center, a platform for art projects to explore new approaches in bridging the community and art making' ${ }^{7}$

According to Indonesian curator Agung Hujatnikajennong, small independent art spaces are beginning to proliferate across Indonesia, operating like urban 'guerrilla' headquarters with 'guerilla' art tactics; they are capable of a flexible, mobile, and adaptable integration of art into the community.

Although alternative spaces offer room for creative practice outside the official sphere, they are not usually equipped to provide staff with professional development opportunities to increase their skills and operational knowledge. Given such spaces often rely on limited resources, temporary infrastructure and provisional funding, they are often disestablished as quickly as they are founded.

As I earlier mentioned, the phenomenon of Asia becoming 'suddenly cultured' describes the region's rushed response to capitalise on the new cultural industries: imperfectly developed art communities leap into staging a host of grand cultural spectacles. The proposal for $\mathrm{M}+$ resulted in suspicion of the government's motives, but also its ability to accomplish such a large-scale project given the lack of bureaucractic flexibility, open-mindedness, and understanding of contemporary art and museum practices. Unease over such unprecedented ambition led some community groups to lobby that the plan be abandoned and a huge park be developed instead. ${ }^{8}$

For an art community suffering from decades of indifference and poverty, however, the sudden investment in art seemed worth pursuing, even at the risk of the project becoming a proverbial white elephant.

\section{The Rich and the Poor}

The WKCD is located on a prime piece of land adjacent to the famous Victoria Harbour. Its location is so outstanding that the developer community believed 'If one gets WKCD, one gets the world'. Situated next to one of the most expensive residential districts of Kowloon, with its beautiful harbour view, the value of this piece of land had already increased by its proximity to wealth - all the cultural facilities of WKCD, as some argued, would surely become the front yards or recreation clubs of the rich. ${ }^{9}$

7 http://wooferlo.blogspot.hk/.

8 Hong Kong Alternatives, 'An Appeal'.

9 Oscar Ho, ‘One Road, Two Very Different Worlds: The Poor and the Rich of West Kowloon', first published in Chinese in Ming Pao, 4 December 2012, http://www.aicahk.org/chi/reviews.asp?id=213. 
Separated by a series of carefully designed roads, on the other side of the luxury apartments of Kowloon, is the Yau Ma Tei district, one of the poorest districts of Hong Kong with a population of aged and ethnic Asian minorities. It is a colourful and culturally diverse neighbourhood where grassroots folk cultures survive precisely because of the absence of opportunities for property development.

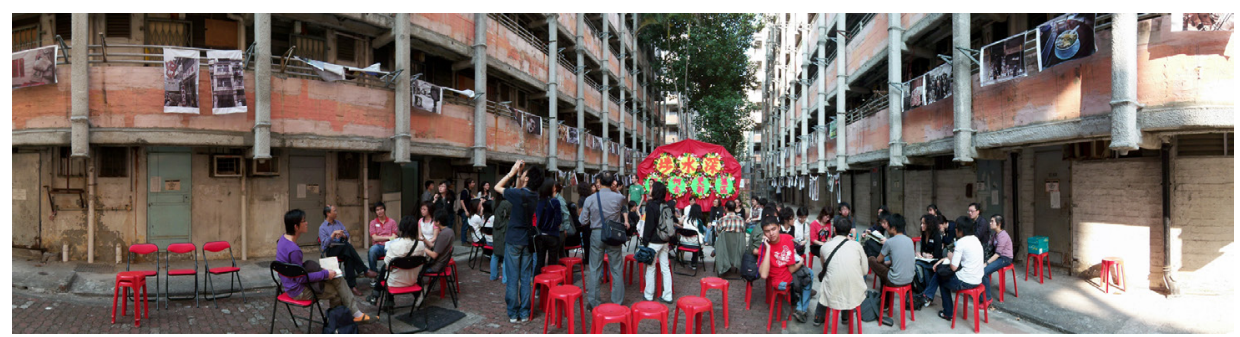

\section{'In Search of Marginalized Wisdom' exhibition seminar, Community Museum Project, Hong Kong, March 2007.}

Image courtesy Siu King Chung

For Hong Kong curator Siu King Chung, the streets of the old district are culturally rich in that they provide unlimited sources of curatorial inspiration. Siu King Chung and his friends have collaborated in organising the Community Museum Project art initiative that does not require a permanent venue; they like to see 'the street as a museum'.$^{10}$ A small, flexible space- or even the absence of space - runs contrary to the new obsession with grand, brand name architecture that is presently favoured by Asian governments. For Siu King Chung and his colleagues, who are charmed by the artistic genius of street culture on the poor side of West Kowloon, the streets are the site and boundless source of inspiration and artworks for their 'museum'. Many of their exhibitions focus on the generally overlooked work created by craftspeople ${ }^{11}$ of the neighbourhood, with the intention of pushing for recognition of their artistic value.

10 Siu King Chung, 'Social Curating in Hong Kong', presentation to the ACN Forum Curatorial Critique: An Asian Context, Hong Kong, 24 May 2011. See also the 'Community Museum Project' website, the independent art initiative with which Siu King Chung is affiliated, http://www.hkcmp.org/cmp/c_001.html: 'Community Museum Project was founded in 2002 in Hong Kong by Howard Chan (art curator), Siu King Chung (design educator), Tse Pak-chai and Phoebe Wong (cultural researchers)'.

11 Some of their exhibits are new designs that have been jointly created by craftspeople and designers. 


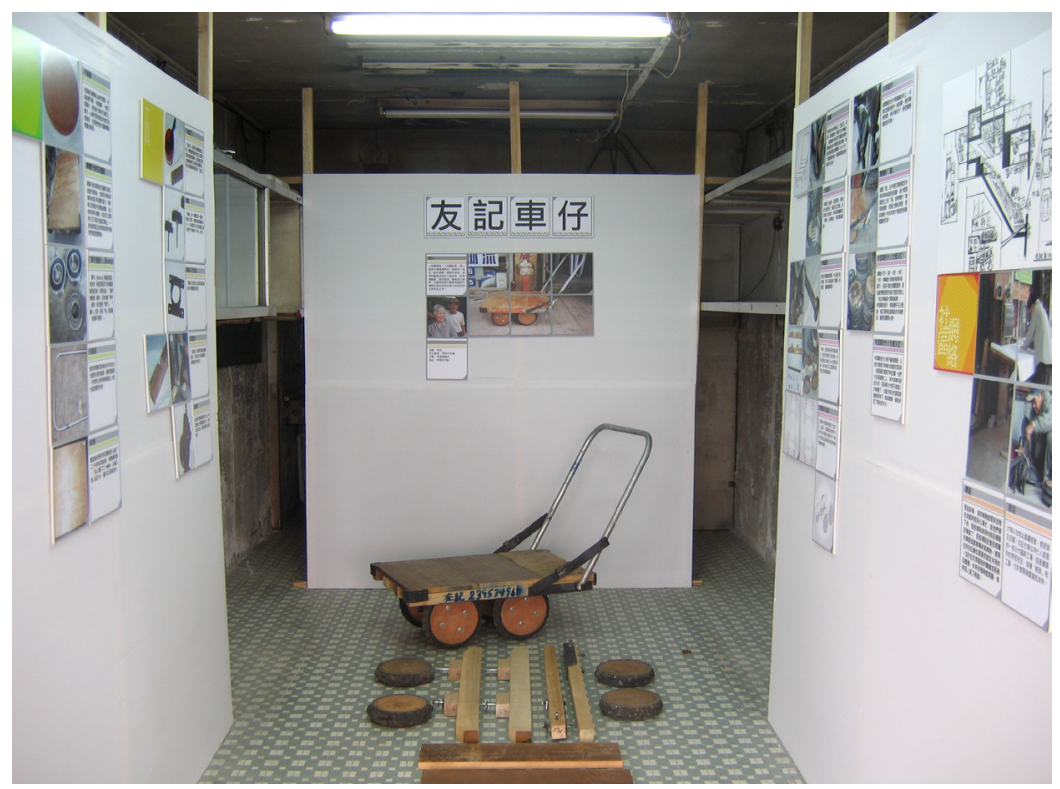

'In Search of Marginalized Wisdom' exhibition, Community Museum Project, Hong Kong, March 2007; wooden cart, crafts.

Image courtesy Siu King Chung

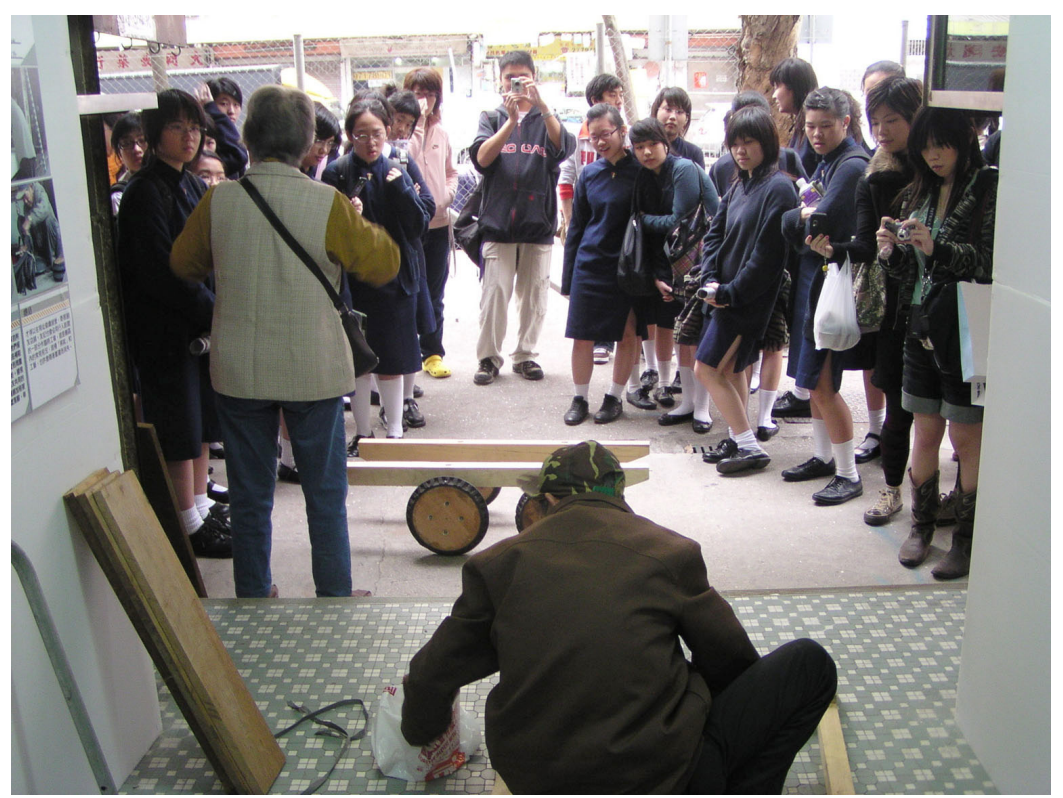

'In Search of Marginalized Wisdom' exhibition, Community Museum Project, Hong Kong, March 2007, wooden cart, crafts demonstration. 


\section{Local Alternative}

With the intention of going beyond conventional modes of thinking about museums, M+ means 'more than a museum'. In avoiding use of the term 'museum' as part of its nomenclature, $\mathrm{M}+$ seeks to address the inadequacy of museums in meeting the cultural needs of ordinary people and seeks to establish alternative languages of cultural presentation, with an orientation toward the local, not just in terms of collection, but also in terms of curatorial perspectives.

As part of its mission, $\mathrm{M}+$ rejects the terms 'modern' and 'contemporary', as these concepts are yet to be, or perhaps do not even need to be, defined within the context of Hong Kong/Asia. Instead, M+ sets its mandates based on the timeframe of the twentieth and twenty-first centuries. The mission also states that $\mathrm{M}+$ needs to adopt a 'Hong Kong perspective' (to be defined by the curators) with an emphasis on 'now' ${ }^{12}$ This mandate registers the importance of perspectives that are sensitive to and meaningful within the local Hong Kong context, and also emphasises the contemporaneity of M+'s collecting and interpretation practices.

Another outstanding feature of $\mathrm{M}+$ is its expansion of the curatorial scope from fine arts to visual cultures. This broadening of definition not only recognises the increased blurring of boundaries in art, but also the strength and uniqueness of Hong Kong culture, which lies not in the narrowly defined concept of 'fine arts' but in a wider context of popular and everyday cultures. In so doing, an expanded definition of 'artistic values' is necessitated.

Hong Kong does not lack rich cultural traditions or an interested audience. The greatest obstacles to a vibrant artistic culture arise from a definition of art that is so narrow and distanced from the public that art has lost its ability to echo and respond to the cultural experience of the local community. In his community museum projects, Siu King Chung and his team discover 'a lot of interesting things from the street, such as the self-made advertisement from the plumber, the funny tools the street carpenters created to build things with'. They proudly declare that 'we do have this kind of indigenous creativity in our culture which has not been made into something prominent in our [local, Hong Kong] culture'. ${ }^{13}$ There is a need to remap and redefine Hong Kong art and culture to uncover this cultural richness and give it the recognition it deserves. Hong Kong's rich cultural tradition is not recognised because the definition of arts and culture is often made by someone else from a distance. The local arts community expected that $\mathrm{M}+$ would help deal with such ignorance.

12 West Kowloon Cultural District, 'M+: About M+ Museum for Visual Culture', http://www.westkowloon. hk/en/mplus/about-m.

13 Siu King Chung, 2011. 
At the ACN forum, Japanese curator Mizuki Endo presented his curated exhibition of photographs tracing the history of the mass suicides of the Okinawa people following the American seizure of the island at the end of the Second World War. This tragic incident, frequently interpreted as a patriotic act of defiance against the Americans was, as Endo argued, in fact orchestrated by the Japanese army. He claimed that the exhibition was not about 'being artistic', ${ }^{14}$ but was a process designed to arouse historical contemplation. Similarly, Cambodiabased curator Erin Gleeson's curation of work by survivors of the Khmer Rouge was also undertaken as an act of dealing with local history. ${ }^{15}$ For both curators, artistic qualities are linked to socio-historical concerns that are generated by a specific time and context meaningful to their particular local community. In other words, these curators have found works of artistic value through a process of recognising the cultural significance of art to local communities.

\section{Inadequate Infrastructure}

Initially the WKCD charmed the arts community with its promise to operate independent of government infrastructure, which was an outstanding breakthrough in changing the mode of governance for major cultural projects. In early 2011 the M+ Advisory Group was dissolved and replaced by a museum committee under the newly established 'WKCD Authority'. The Home Affairs Bureau, the department in charge of general community affairs including recreation, culture and waste management, was assigned to support the implementation work. Following a practice adopted since colonial days, the government transferred the administration officer originally assigned to the project to another department after three years of service. Just when this officer had acquired the requisite knowledge and sensibility toward arts and cultural development, they were reassigned. Subsequently an officer from an area unfamiliar with arts and culture moved in to the leading position to work with a few members of the former group who were appointed to serve on a new museum committee. ${ }^{16}$ The operation of $\mathrm{M}+$ thus remains within a mechanism dictated by the changing terms of bureaucracies and without guarantee of sufficient and ongoing arts and culture professional expertise.

14 Mizuki Endo, presentation to the ACN Forum Curatorial Critique: An Asian Context, Hong Kong, 24 May 2011.

15 Erin Gleeson, 'Curatorial Landscape in Cambodia', presentation to the ACN Forum Curatorial Critique: An Asian Context, Hong Kong, 24 May 2011.

16 In 2010, when the committee hired a consultant to undertake research for $\mathrm{M}+$, a member of the disbanded advisory group was recruited to explain the concept of $\mathrm{M}+$ to the consultant. This demonstrated the lack of corporate knowledge passed from one administration group to the next: the newly formed administration lacked the corporate knowledge to provide such an explanation to the consultant. 
The search for 'software' for $M+$ revealed the inadequacy of the existing infrastructure. Because civil servants run all major museums, the government apparatus plays a significant role in shaping the 'culture for conducting cultural development'. The culture of the civil service promotes rules and order, values collective decision-making, does not tolerate ambiguity and opposes risktaking. Such a bureaucratic operational model is in fundamental opposition to artistic/creative projects, which demand experimentation, risk-taking and personal endeavour.

Another characteristic of the civil service is its 'incestuous' nature. Promotion to senior positions is an in-house practice based on seniority and length of service within the hierarchy, rather than on the knowledge or professional expertise of the individual. The exclusivity of the system offers little opportunity for anyone outside the civil service to enter public museum administration. As I mentioned earlier, independent arts organisations are, on the other hand, often unable to provide professional development training and, consequently, often struggle to nurture professionals who are capable of working at larger cultural institutions.

Conceptually, $\mathrm{M}+$ is too unconventional for Hong Kong's current civil servant culture, too complex for the decision-makers unfamiliar with arts and culture, and too big for the existing cultural framework. The import of overseas support is, thus, an inevitable consequence.

Despite efforts to build an institution that reflects local cultural experiences, and to establish a language to articulate local Hong Kong culture, the cracks in the existing infrastructure, the imbalance of power between the bureaucracy and non-government cultural workers and, most significantly, the continuing prevalance of the colonial mindset, make it difficult to shape and establish the distinctive vision for $\mathrm{M}+$.

\section{Colonial Legacy}

When the Hong Kong Government first presented the WKCD proposal in 2006, the inclusion of a canopy designed by Foster was a mandatory requirement in any proposal submitted. The insistence on adopting Foster's design was only abandoned after architects, engineers and cultural professionals criticised the cost and difficulties in maintaining the proposed massive canopy that would cover the 40-hectare site. ${ }^{17}$

17 Polly Hu, 'Cost May Scupper Canopy for Culture Hub', South China Morning Post, 28 April 2004, accessed 1 April 2014, http://www.scmp.com/article/453803/cost-may-scupper-canopy-culture-hub. 
However, the desire to have Foster involved in the project persisted. After the new proposal was submitted, an open competition was held inviting proposals for an overall design of WKCD. Three finalists were selected: one local (from Hong Kong) and the others from the United Kingdom and Sweden. ${ }^{18}$ There was no surprise in 2010 when Foster's architectural firm was announced as the final choice. Foster's landmark buildings are situated all over Hong Kong and the city can be considered as his private showroom: in addition to the HSBC headquarters there are major public buildings including Hung Hom train station, Chek Lap Kok International Airport, the recently built Kai Tak Cruise Terminal, and the upcoming WKCD which are all projects led by Foster. As the chosen architects for M+, Foster + Partners, together with the appointment of the firm Herzog \& de Meuron (architects of the Tate Modern, London), proves that, culturally, the British colonial legacy lives on. Years after unification with China, the cultural or psychological affiliation with Britain persists, particularly among senior decision-makers within the bureaucracy of cultural development. Seeking support and inspiration from the former coloniser is a customary, almost instinctive act.

The first director of WKCD, Graham Sheffield, is a former director of the Barbican Centre in London. Michael Lynch, an Australian and once chief executive of the Southbank Centre in London, replaced him after five months. Swedish curator Lars Nittve was recruited in 2011 as director of $\mathrm{M}+$. He is best known as the founding director of the Tate Modern at Southbank, London.

The curatorial team of $\mathrm{M}+$ consists of an American-Korean, a German who worked in Hong Kong for a few years, and three Chinese from Beijing, who once worked in the United States. For nearly three years, the senior curatorial team operated without a role being played by anyone from the local Hong Kong community, or anyone capable of understanding Cantonese. ${ }^{19}$ The museum operates, therefore, with an existing deficit in understanding local culture, particularly popular culture.

The 'import' of foreign experts is a frustrating, but inevitable, consequence of attempts to meet the needs of rapid cultural expansion. ${ }^{20}$ The inability of outsiders to articulate local cultures can only be resolved by their willingness to understand and explore those cultures with sincerity and even humility.

The number of $\mathrm{M}+$ curators from Mainland China presents another source of tension. Mounting resentment exists among the people of Hong Kong towards

18 The three finalist architectural firms were OMA (Sweden), Foster + Partners (United Kingdom) and Rocco Design Architects (Hong Kong).

19 In March 2014, after more than three years, a local person from Hong Kong was employed to join the senior curatorial team to look after the section focusing on Hong Kong art.

20 Chan Yuen-han, 'Change the Destiny of WKCD by Changing its Name', $A M 730$ (2013) accessed 7 October 2013, http://www.am730.com.hk/column-162512.CHAN Yuen-han. 
what they perceive as political and cultural colonisation from Mainland China; the employment of curators from Beijing to run a cultural institution that interprets Hong Kong culture is interpreted by some as an insensitive act of provocation.

\section{Art for the People}

In addition to the geographic gap between rich and poor, the adoption of aesthetics that are familiar to foreign experts only reinforces the sense of alienation for mainstream Hong Kong audiences. The existing tendency to favour art that is based on a Western set of artistic criteria might delight a small community of local elitists, but it will only further alienate the mainstream public.

In a critique of the continuation of the colonial mode of governance, journalist Vivienne Chow states that:

The appointment of the board members [of the WKCD Authority] closely resembles the early colonial days when the colonial government, which had troubles with dealing with the local Chinese population at the time, gave the rich Chinese the power to sort things.

She rightly points out that structural elitism contradicts the original spirit of the project:

the majority of these figures represent the society's upper class. They obviously speak the same 'language' to the team's 'imported elites', which enjoy a great reputation in the international contemporary art world. Thus one cannot help but wonder if $\mathrm{M}+$ only represents the tastes of a small circle of elites, imposing their elite ideas onto a general public of Hong Kong that lacks 'cultural capital' to understand arts and culture. ${ }^{21}$

Chow vividly illustrates a frustrating situation that is becoming obvious not just in Hong Kong, but also in the other 'suddenly cultured' regions of Asia.

Establishing new cultural spaces, such as $\mathrm{M}+$, also poses the problem of building a collection that is meaningful to local Hong Kong people. $\mathrm{M}+$ intends to introduce a perspective on art that rests outside a Western-defined aesthetic framework. Turning to the interdisciplinary field of 'visual culture', $\mathrm{M}+$ broadens the definition of art and highlights the aspects of culture that are closely linked to local histories and people, such as Hong Kong's leading role in pioneering Chinese political comics during the late Qing Dynasty; its unique role as a haven of court literati culture after the collapse of the dynasty;

21 Vivienne Chow, 'A Series of Unfortunate Events: The Past and Present of West Kowloon Cultural District', Cultural Vision (May 2013). 
the anti-Japanese and, later, civil war propaganda art of the 1930s and 1940s; the brief but significant Leftist Renaissance of the late 1940s, especially in the area of popular publications; the conflicting dynamic between the north (Shanghai) and south (Guangdong) of the 1950s in literature and film; and, the "not quite East or West' pop culture of the 1960s that emerged against the background of the Cultural Revolution in China. One does not always need to look to the West for artistic excellence, as long as one is willing to take a look at what the locals already have.

Unfortunately, to this point, the $\mathrm{M}+$ collection is defined mainly by the prevailing category of 'contemporary art' premised on 'global' artistic vocabularies. The curatorial team ignores, or is simply unable to understand, the histories and realities of the art and culture of Hong Kong.

\section{The Fallacy of 'Global is Local'}

While $\mathrm{M}+$ recognises the coexistence of the local and global, its original plan highlights the importance of local culture. There is also a necessity to deal with the definition of the 'global', and the existing imbalance between the 'global' and the 'local'. The recently published acquisition policy of M+ states that it will 'deploy this recent and more global concept of "art"". ${ }^{22}$ This policy reflects an emphasis on 'contemporary' and 'global' art, a field that is familiar to the current curatorial team. The original mandate of recognising the local is downplayed and no explanation is given to justify the change.

In a defence against the criticism that $\mathrm{M}+$ does not pay attention to the local, and the critique that $\mathrm{M}+$ equates 'global' with 'Western', Nittve asked 'Is universal suffrage a Western idea or a global idea? ${ }^{23}$ Of course there are globally recognised values that are arguably generated in the West, but that does not also mean that Damien Hirst or Pablo Picasso are necessarily global. One can just as easily ask: 'Is Cantonese opera global?'

The existence of something distinctively local is an undeniable fact that cannot be obscured by wordplay. The recognition of the local and the imbalance between 'global' and 'local', which has existed in Hong Kong since colonial days, must be addressed. Until the turn of the twenty-first century, Hong Kong liked to describe itself as a 'cultural desert'. The practice of culturally degrading the locals was part of the system of colonial control. Within the academic

\footnotetext{
22 West Kowloon Cultural District Authority, 'M+ Acquisition Policy' (2013), accessed February 2013, http://www.wkcda.hk/filemanager/en/content_283/Mplus_Acquisition_Policy_eng.pdf.

23 Vivienne Chow, 'M+ Chief Lars Nittve Vows Museum Won't Steer Clear of Politics', South China Morning Post, accessed 4 May 2013, http://www.scmp.com/news/hong-kong/article/1229502/m-chief-lars-nittvevows-museum-wont-steer-clear-politics.
} 
establishment there was little research undertaken before the 1990s on local art and culture. A history of Hong Kong art that is acceptable to local critics has yet to be written. ${ }^{24}$

Gleeson rightly pointed out at the ACN forum that in Cambodia her 'curatorial practice was really a conscious effort to write and facilitate an art history that does not yet exist'. ${ }^{25}$ In Hong Kong, as in many of its Asian counterparts, the lack of archival work and research on Hong Kong's art and culture makes it difficult to create an intellectual base for the curation of historical exhibitions and the building of collections. Instead of settling for art that has been already 'endorsed', the establishment of M+ demands ongoing research into local art and cultural history. Unfortunately there is as yet no mechanism to support such scholarship, despite the museum having begun collecting and curation. Staying within the arena of contemporary art as understood by the West continues to be the priority.

The esoteric, rarefied and indifferent attitude of $\mathrm{M}+$ persists and the distance between the public and 'art' remains. According to Gleeson, getting to know the local means 'trying to bring in other conversations' ${ }^{26}$ The issue is not about the coexistence of the global and local; rather, it is about the struggle against the domination of one over the other. Modern curatorial practice has, arguably, been strongly shaped by the West, as in the case of Indonesia described by Hujatnikajennong. Equating 'global' with 'Western', overemphasising 'global' as an all-embracing standard, and downplaying the existence of the 'local', demonstrates a disturbing colonial mindset. In order to stand culturally on one's own, such cultural injustice must be addressed.

\section{Chinese Art for the West}

In $2012 \mathrm{M}+$ announced a major donation valued at $\mathrm{HK} \$ 1.3$ billion (US\$167.5 million) ${ }^{27}$ from the Swiss art collector Uli Sigg. The donation was in turn accompanied by $\mathrm{M}+$ 's obligation to purchase from the donor a further 47 works for HK\$177 million (US\$22.8 million). The collection includes some works from the late 1970s and 1980s, but it mainly comprises Chinese contemporary art produced after 2006. The amount spent is equivalent to one tenth of the total

\footnotetext{
24 Mainland Chinese historian Zhu Qi wrote a History of Hong Kong Fine Art (2005) that received harsh criticism from the local arts community for its academic inadequacy and political inclination. Edwin Lai Kin-keung, 'On Hong Kong Art History', Independent Media (2006), accessed 7 October, 2013, http://www. inmediahk.net/node/91226.

25 Gleeson, 2011.

26 Ibid.

27 Estimated by Sothebys.
} 
budget for $\mathrm{M}+$ to build its base collection. The donation plus purchase generated much debate over values and meaningfulness of arts and culture in relation to the vision and mission of $\mathrm{M}+$ and the cultural experience of the locals.

The original $\mathrm{M}+$ collecting plan includes a mission to collect material from outside Hong Kong, including Mainland China. The current administration must, however, clarify the reasons for such a substantial investment in art from mainland China instead of from Hong Kong, and the inclusion of these works as the core of the $\mathrm{M}+$ collection. ${ }^{28}$ The question is, what does Chinese 'contemporary art' mean to Hong Kong? In justifying the collection of Mainland Chinese contemporary art, Nittve stated that 'what happened after the Cultural Revolution is extremely important. It affects us [Hong Kong], and it's affected by what happened here' ${ }^{29}$ Given that practically everything that happens in China affects Hong Kong, such a general statement is essentially meaningless. In reality, the Mainland Chinese contemporary art that is favoured by the West has limited cultural impact on Hong Kong. In contrast, the pop culture of Hong Kong, for example, had and continues to have a tremendous impact on China.

It is true that, since the mid-1990s, Hong Kong has played a significant role in marketing Chinese contemporary art to the world. ${ }^{30}$ With the exception of a small community of interested artists, collectors and dealers, however, such art does not impact on Hong Kong people. By comparison, other Chinese art movements have a profound influence, including the Lingnan School and the Woodcut Movement advocated by Lu Xun during the 1930s and 1940s. More recently, 'Chinese contemporary art' is a form of exported art that has had far less impact on the development of Hong Kong art except in terms of its influence in opening up an art market.

\section{Submerging the Popular}

Ignorant of the richness of local culture, particularly the grassroots culture evolving from Cantonese refugees, $\mathrm{M}+$ has so far failed to address the aspects of local culture that are most distinctive to Hong Kong and were specifically highlighted in its original plan.

The recent decision to revoke popular culture as a distinct $\mathrm{M}+$ acquisition policy area is a blatant denial of the cultures of the ordinary people, who are

\footnotetext{
$28 \mathrm{M}+$ argues that, in terms of the number of works, the collection holds more Hong Kong artworks than works of Mainland Chinese contemporary art, but it has not revealed the amount spent on local Hong Kong arts. 29 Chow, 'M+ Chief Lars Nittve Vows Museum Won't Steer Clear of Politics'.

30 The first major exhibition of Chinese contemporary art was held at the Hong Kong Arts Centre in 1993, curated by Li Xianting, Oscar Ho and Johnson Chang.
} 
also the richest part of Hong Kong culture. ${ }^{31}$ Critic Anita Tse criticised the policy, remarking that ' $\mathrm{M}+$ is run by a curatorial team of foreigners who do not understand the importance of "popular culture" in Hong Kong. ${ }^{32}$

Responding to criticism that $\mathrm{M}+$ is submerging Hong Kong's popular culture into other art forms, instead of allowing it to have its own distinctive place in the collection as $\mathrm{M}+$ originally proposed, Nittve argues that 'popular culture is often represented as the flip side of fine art in the West, but this kind of differentiation is irrelevant here, as many creative works were conceived for commercial platforms. Popular culture is therefore represented in each of the three major categories'. ${ }^{33}$ Such a statement shows a lack of understanding of the distinctive cultural history of Hong Kong.

Historically Hong Kong has experienced a separation and, thus, distinction between 'fine' and 'popular' art. Inheriting a literati tradition that was described as conservative by the progressive intellectuals of the first half of the twentieth century and, at the same time, suffering from a lack of support for such literati practice, the early generations of artists who fled to Hong Kong from Mainland China were forced to make a living from applying their skills to popular culture. The artist Lee Bing in the 1930s and 1940s lived a typical double life, consciously creating 'art' as social critique (also to generate some occasional income) on the one hand and, on the other, painting giant advertising billboards for cinemas. The dichotomy of these two art forms running parallel to each other has become a major creative topic among a generation of artists, such as Lau Yee Cheung (Liu Yichang). ${ }^{34}$

Artist Law Kwun Chiu is best known across the Asian diaspora for his romantic illustrations of life in his hometown in the Guangdong Children's Paradise magazine. For decades since the 1950s the magazine has charmed millions of Chinese readers throughout Asia. It has not only made Law Kwun Chiu famous, but it has also extended the cultural influence of Hong Kong to its neighbouring regions. In private, the only creations that Law Kwun Chiu himself recognised as art were his traditional ink paintings of mountains and mist. ${ }^{35}$ After working as a propaganda artist during the Second World War, against Japanese invasion,

\footnotetext{
31 Chan Yuen-han, 'Change the Destiny of WKCD by Changing its Name'.

32 Anita Tse, 'Another Discussion about Getting Rid of Popular Culture at M+', House News, accessed 7 October 2013, http://thehousenews.com/art.

33 Chow, 'M+ Chief Lars Nittve Vows Museum Won't Steer Clear of Politics'.

34 Lau Yee Cheung's novel Tête-bêche (對倒) (1975), which was about the anxiety between art and the popular, was made into the movie In the Mood for Love (2000) by Wong Kar-Wai.

35 I interviewed Law Kwun Chiu in preparation for an exhibition in the mid-1990s. At first, he refused to show his illustration work and only wanted to show his ink paintings, as he believed those were more dignified and artistic. Such reticence is not limited to visual arts. Another outstanding example of creativity that encompasses popular and traditional culture is the work of literary scholar and artist Jin Yong (Louis Cha Leung-yung), whose kung-fu novels have fascinated generations of Chinese all over the world since the 1950s and have been influential on many kung-fu movies.
} 
Law Kwun Chiu found a liberating freedom in not having to make art with political or patriotic missions to fight against the Japanese or to revitalise China, as every Chinese intellectual did at that time. In Hong Kong, through paid work as a commercial artist, he was freed from the heavy burden of traditional or patriotic obligations. It was in the refugee shelter of Hong Kong that popular culture came to hold special meaning for the artist through its detachment from official culture and obligations. Artists may find creative liberation through popular culture and the opportunity to pursue a different path that results in outstanding artistic creativity.

The collection of baseball cards that is held by the Metropolitan Museum in New York is not given a distinct categorisation. $\mathrm{M}+$, on the other hand, must make popular culture a unique and recognised category within its collection. Understanding the significance of popular culture in Hong Kong will ensure that it cannot be easily submerged in other art forms. Downplaying the significance of popular culture, however, will limit the opportunity for $\mathrm{M}+$ to be a space devoted to visual cultures and will reduce it, rather, to a space for visual arts, which is presumably an achievable goal for the foreign experts.

\section{A Post-Colonial Failure}

WKCD marks the end of decades of indifference to the development of culture in Hong Kong. The grand undertaking, which was built around the fantasy of the economic potential of the cultural industries, was in fact a real estate project in disguise. After much controversy the project was turned back into something seemingly cultural. It is under such unusual circumstances that the idea of $\mathrm{M}+$ was conceived. It signifies an attempt to move beyond the conventional, Western-based concept of art and museum.

To achieve the vision of $\mathrm{M}+$, one needs to recognise the imbalance between global and local (and that the 'global' should not be synonymous with 'Western'). At the same time, an underdeveloped and imbalanced cultural ecology that is dominated by civil servants creates gaps in administration that inevitably require help and advice from external professionals. If there is no enduring engagement with local cultures, or the will or ability to understand them, these experts can retreat into their familiar vocabularies and modes of practice. This shortfall in the scope of $\mathrm{M}+$ is evident when compared with the original vision and mission for the institution. 


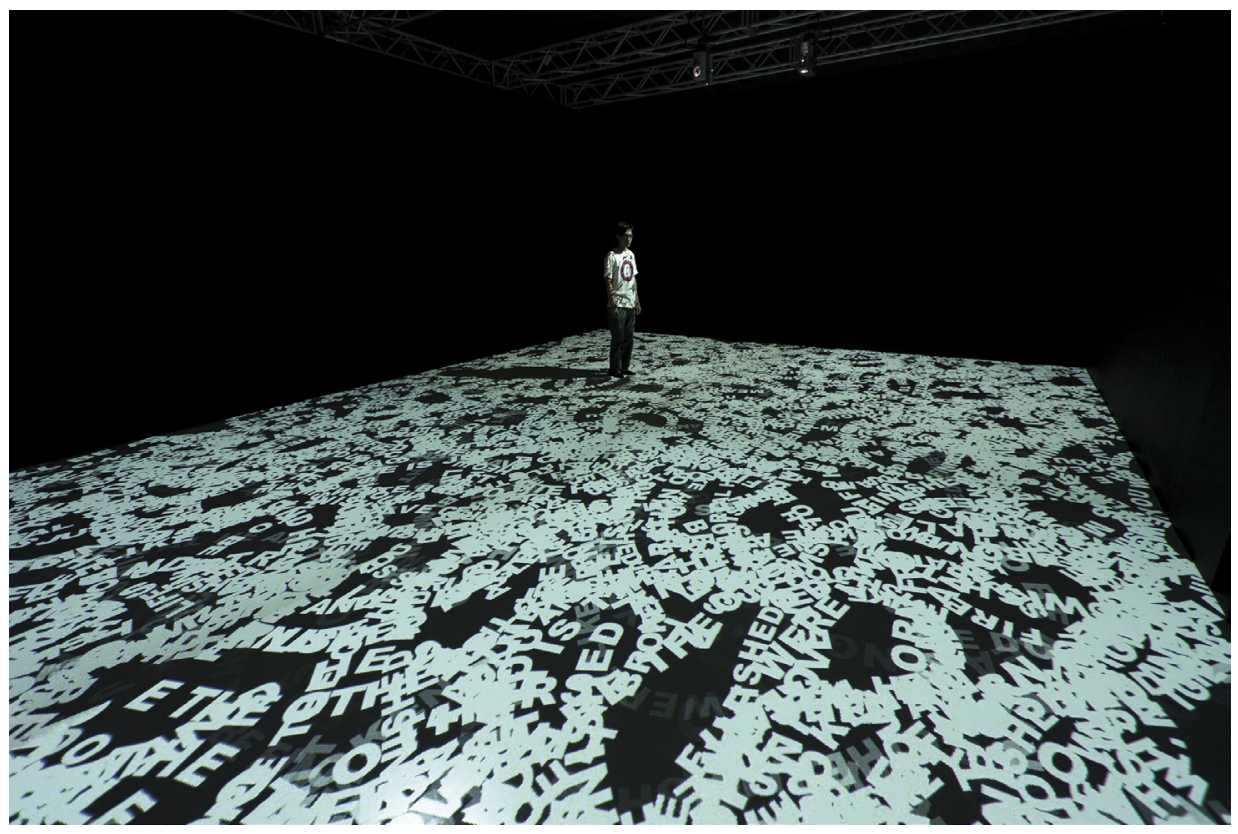

Tsang Kin-wah, The Fourth Seal at Mobile M+: Yau Ma Tei 2012.

Courtesy of M+, West Kowloon Cultural District

Underpinning the original vision and mission of $\mathrm{M}+$ was the stated desire to claim cultural recognition for Hong Kong and to review and expand the conventional modes of museum operation in order to be inclusive of Hong Kong's diverse visual culture. Ultimately, however, $\mathrm{M}+$ looks set to become just another museum of contemporary art, an $\mathrm{M}$ without a + , or even an $\mathrm{M}-$. It is possible that $\mathrm{M}+$ will be another example of the futility of Asia's struggle to establish its own creative languages outside a Western-dominated art world.

The editorial board of the journal Cultural Vision posted a question to Nittve in May 2013, asking 'M+ was set up to be a new cultural institution. How will it live up to the expectation, and distinguish itself from merely being an Asian pirated copy of MoMA or Tate Modern?'36 So far, there has been no reply.

36 Editorial board, question to Dr Lars Nittve, Executive Director of M+, Cultural Vision (2 May 2013), 54. 
This text taken from Contemporary Asian Art and Exhibitions: Connectivities and world-making, by Michelle Antoinette and Caroline Turner, published 2014 by ANU Press, The Australian National University, Canberra, Australia. 